\title{
Energy metabolism in the pancreas of ground squirrels (Spermophilus citellus) during prolonged cold exposure and in hibernation
}

\author{
${ }^{1}$ Aleksandra Jankovic, ${ }^{1}$ Andjelika Kalezic, \\ ${ }^{1}$ Strahinja Djuric, ${ }^{2}$ Aleksandra Korac, \\ 'Biljana Buzadzic, 'Bato Korac \\ ${ }^{1}$ Department of Physiology, Institute for Biological \\ Research "Sinisa Stankovic" National Institute of \\ Republic of Serbia; University of Belgrade, \\ Bulevar despota Stefana 142, Belgrade, 11060, Serbia; \\ 2 Center for Electron Microscopy, Faculty of Biology, \\ University of Belgrade, Studentski trg 16, Belgrade, \\ 11000, Serbia \\ Corresponding author: \\ Prof Bato Korac \\ Department of Physiology, Institute for Biological \\ Research "Sinisa Stankovic", National Institute of \\ Republic of Serbia, University of Belgrade, \\ Bulevar despota Stefana 142, Belgrade, 11060, Serbia \\ Phone/fax: (381-11)-2078-307, (381-11)-2761-433 \\ E-mail address: koracb@ibiss.bg.ac.rs
}

\begin{abstract}
Mammalian hibernators undergo a host of biochemical adaptations that allow them to survive the harsh cold environment and food restriction. Since the energy metabolism of the pancreas during hibernation remains unknown, we investigated the molecular basis of mitochondrial energy-producing pathways in line with their regulating mechanisms, as well as the (re)organization of antioxidative defence in the pancreas during the prehibernation period and in the hibernating state. To this end, male ground squirrels (Spermophilus citellus) were divided into two groups, the control group kept at room temperature $(22 \pm 1$ $\left.{ }^{\circ} \mathrm{C}\right)$ and the group exposed to low temperature $\left(4 \pm 1{ }^{\circ} \mathrm{C}\right)$. Active animals from the cold exposed group were sacrificed after 1, 3, 7,12 , and 21 days; animals that entered hibernation were sacrificed after 2-5 days of torpor. Our results showed that the protein levels of respiratory complexes I, II, IV and cytochrome c were increased in response to prolonged cold exposure (from day 12) and that such expression profiles were maintained during hibernation. In parallel, AMP-activated protein kinase a (AMPKa) and nuclear respiratory factor 1 (NRF-1) were shown to be upregulated. Moreover, prolonged cold exposure and hibernation induced an increase in the protein expression of antioxidative defence
\end{abstract} enzymes copper-zinc superoxide dismutase (CUZnSOD) and glutathione peroxidase (GSH-Px). In conclusion, these results point to a controlled metabolic remodeling in the pancreas of ground squirrels during prolonged cold exposure and in hibernation, which includes an improvement of mitochondrial oxidative capacity along with a proportional upregulation of antioxidative defence.

Key words: hibernation; energy metabolism; antioxidative defence; pancreas.

\section{INTRODUCTION}

Many species have evolved to hibernate during the winter months as a means of maintaining energy homeostasis in such challenging circumstances $[1,2]$. The hibernating state is characterized by prolonged bouts of torpor during where basal metabolic rates are suppressed to $2-4 \%$ of active metabolic rates while essential physiological and many energy-demanding cellular processes continue at a markedly reduced rate $[2,3]$. Bouts of torpor are spontaneously interrupted by arousals, periods of intense metabolic activity during which physiological parameters are promptly restored [1].
This apparent metabolic and functional plasticity is based on the ability to modulate mitochondrial metabolism and energy-producing pathways. Significant decreases in levels of ATP have been detected in brain, kidney and skeletal muscle tissues [4]. However, energy metabolism is maintained in a few select tissues, mostly in those responsible for overall energy homeostasis and thermogenesis, such as heart, liver, brown adipose tissue (BAT) and white adipose tissue (WAT). Studies of non-hibernators have shown that metabolic remodeling during cold acclimation is tissue specific and that significant changes to mitochondrial oxidative capacity (OXPHOS) and regulatory mechanisms 
therefore occur in metabolically active tissues such as skeletal muscle and BAT [5,6]. These changes support a higher basal metabolism which is needed to maintain energy homeostasis, i.e. body temperature during cold acclimation. Along with the changes in metabolic pathways, reorganization of antioxidative defence occurs in order to maintain tissue redox homeostasis [79]. To the best of our knowledge, there are no studies that consider the energy metabolism of the pancreas during prehibernation and hibernation, despite its significant role in the regulation of whole-body metabolism. With that in mind, we focused on the molecular basis of mitochondrial bioenergetic potential (OXPHOS components) along with their regulatory mechanisms, AMP-activated protein kinase a (AMPKa) and nuclear respiratory factor 1 (NRF-1), as well as antioxidant defence (AD) in the pancreas of ground squirrels during cold acclimation and hibernation.

\section{MATERIAL AND METHODS}

\section{Animals}

The experimental protocol was approved by the ethical committee for the treatment of experimental animals of the Institute for Biological Research, Belgrade, Serbia. Adult male European ground squirrels (Spermophilus citellus) were trapped during mid-July in the Deliblatska peščara (southeastern part of Vojvodina, Serbia) and transported to the animal facility at the Institute for Biological Research, Belgrade, Serbia. Ground squirrels were housed in individual plastic cages at room temperature and fed rodent chow, fresh carrots, and apples ad libitum until early September when one group continued to be maintained under these conditions (control group) and another group was moved to a cold chamber set to an ambient temperature of 4 $\pm 1{ }^{\circ} \mathrm{C}$, with food and water ad libitum. Active, euthermic squirrels that did not enter into hibernation under these low temperature conditions were sampled as the cold-exposed group and were sacrificed after 1, 3, 7, 12 , or 21 days. Animals that entered into torpor (hibernation group) were sampled after each individual had been hibernating for 2-5 days (as indicated by continuous rectal temperature reading of $\sim 4{ }^{\circ} \mathrm{C}$ ). Control animals were sampled on the same day as the hibernating ones. All animals were sacrificed by decapitation between 8 and 10 a.m. to avoid any cyclic daily variations. Pancreatic tissue was removed within 3 min, perfused with cold saline and minced. Minced tissues were washed thoroughly to remove all traces of blood and were snap-frozen in liquid nitrogen and stored at $-80{ }^{\circ} \mathrm{C}$ until subsequent Western blotting.

\section{SDS-PAGE and Western blotting}

Western blots were conducted as described previously $[10,11]$ using antibodies against the Ndufa9 subunit of

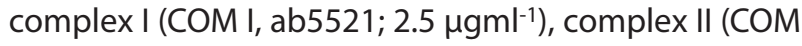
II, ab14715; $0.1 \mathrm{\mu gml}^{-1}$ ), complex III (COM III, ab14745; $0.5 \mathrm{gm}^{-1}$ ), subunit IV of cytochrome $c$ oxidase (COX IV, ab14744; $0.1 \mathrm{\mu gml}^{-1}$ ), cytochrome $c$ (ab18738; $1.0 \mathrm{\mu gml}^{-}$ 1), ATP synthase (ab14730; $0.8 \mathrm{\mu gml}^{-1}$ ), phosphorylated AMPK-activated protein kinase a (phospho-AMPKa, Millipore, 07-681; $2.0 \mathrm{\mu gml}^{-1}$ ), NRF-1 (ab86516; 1.0 $\mathrm{ggml}^{-1}$ ), copper-zinc superoxide dismutase (CuZnSOD, ab13498; $\left.0.2 \mathrm{\mu gml}^{-1}\right)$, manganese superoxide dismutase (MnSOD, ab13533; 1:5000), catalase (CAT, ab1877; 1:1000), glutathione peroxidase 1 (GSH-Px 1, ab16798; 1:2000), and beta-actin (ab8226; 1:1000). Quantitative analysis of immunoreactive bands was conducted with ImageJ software [12]. Band volume was the sum of all the pixel intensities within a band, i.e., 1pixel = $0.007744 \mathrm{~mm}^{2}$. We averaged the ratio of dots per band for the target protein and beta-actin in corresponding samples from three similar independent experiments, and expressed them relative to the euthermic control, which was standardized as $100 \%$. Data were then statistically analyzed.

\section{Additional assays and statistical analysis}

Protein content was estimated using bovine serum albumin as a reference [13]. Analysis of variance (ANOVA) was used to test within-group comparisons. If the $F$ test indicated an overall difference, Tukey's $t$ test was applied to evaluate the significance of the differences. Statistical significance was set at $p<0.05$.

\section{RESULTS}

The changes in protein expression of oxidative phosphorylation (OXPHOS) components in the pancreas of ground squirrels during cold acclimation and hibernation are shown in Figure 1. Protein levels of complex I were maintained at control levels during the initial phase of cold exposure, but the expression was increased in the late stage of cold acclimation (days 12 and 21). This high protein level of complex I was maintained in hibernation $(p<0.01)$. Similarly, protein content of complex II was maintained during the initial phase and increased more than 2-fold on days 12 and 21 ( $p<0.001)$. Protein levels of complex III were increased on day 3 as well as in hibernation $(p<0.01)$. Low temperature induced an increase in the protein content of complex IV, also on days 12, 21 ( $p<0.01$ and $p<0.001$, respectively) and in hibernation ( $p<0.05$ ). Protein level of cytochrome $c$ showed an increase from day 7 onwards, peaking on day $21(p<0.001)$ and in hibernation $(p<0.01)$. However, levels of ATP synthase were slightly decreased during cold acclimation and hibernation.

The expression pattern of AMPKa and NRF1 during cold acclimation corresponds to the changes seen in OXPHOS components (Figure 2). Levels of AMPKa 


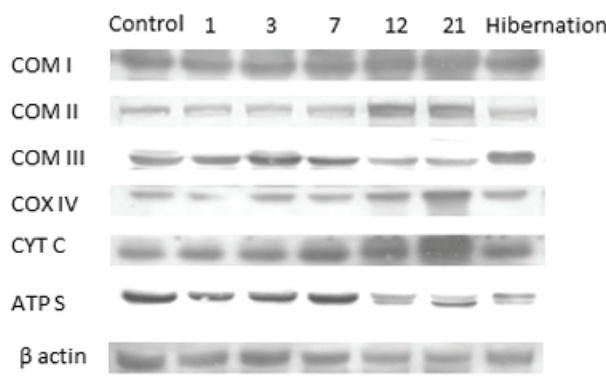

A

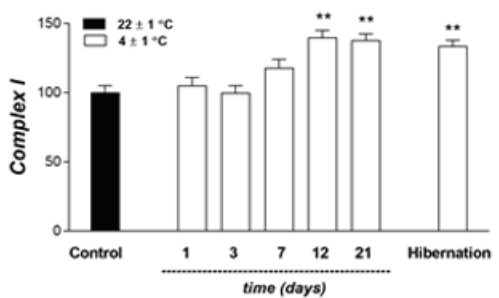

D

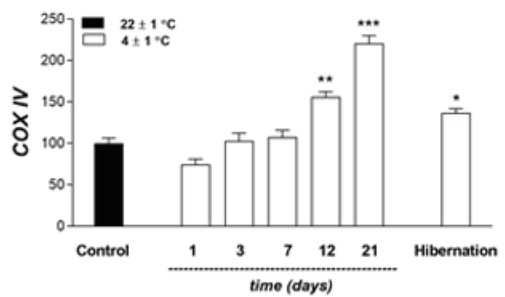

B

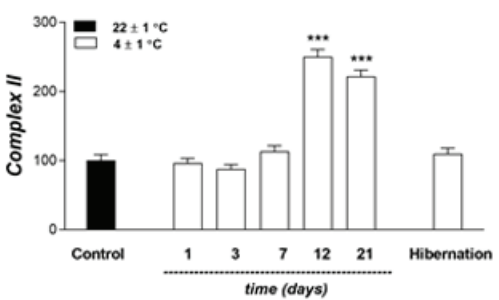

E

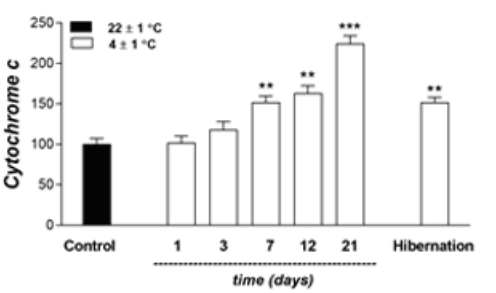

C

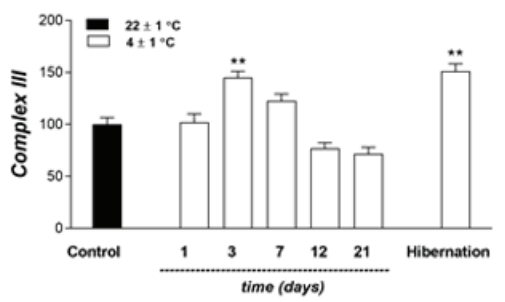

$\mathbf{F}$

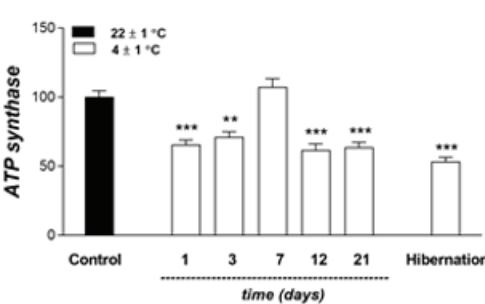

Figure 1. Change in protein content of oxidative phosphorylation components: (A) complex I (COM I), (B) complex II (COM II), (C) complex III (COM III), (D) subunit IV of cytochrome c oxidase (COX IV), (E) cytochrome c (CYT C), (F) ATP synthase in the pancreas of cold exposed (1, 3, 7, 12, or 21 days) and hibernating (2-5 days) ground squirrels. The protein content is expressed relative to a euthermic control, which was standardized as $100 \%$. The signals from representative Western blots are shown. Bars represent the mean \pm S.E.M of three independent immunoblots.

${ }^{*}$ Compared to euthermic control, ${ }^{*} p<0.05,{ }^{* *} p<0.01,{ }^{* * *} p<0.001$.

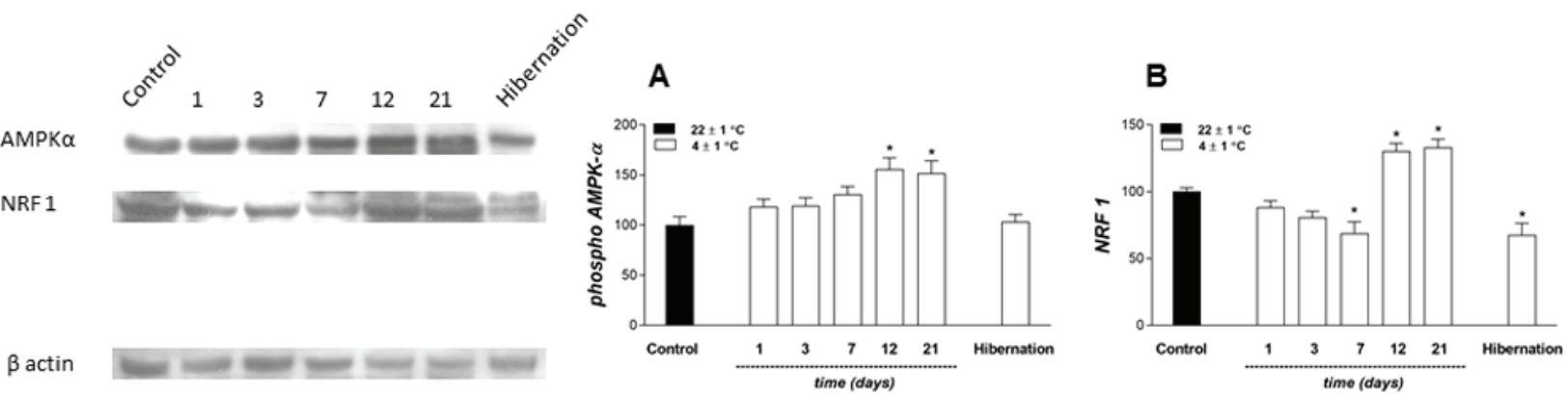

Figure 2. Protein expression of (A) phosphorylated AMP-activated protein kinase a (phospho AMPKa) and (B) nuclear respiratory factor 1 (NRF-1) in the pancreas of cold exposed (1, 3, 7, 12, or 21 days) and hibernating (2-5 days) ground squirrels. The protein content is expressed relative to a euthermic control, which was standardized as $100 \%$. The signals from representative Western blots are shown. Bars represent the mean \pm S.E.M of three independent immunoblots.

*Compared to euthermic control, * $\mathrm{p}<0.05$.

were increased about 1.5 -fold on days 12 and $21(p<$ 0.05). Protein content of NRF-1 also showed a slight increase on days 12 and 21 , but decreased on day 7 and in hibernation $(p<0.05)$.

Cold exposure induced significant changes in protein levels of antioxidant enzymes (Figure 3). Protein content of CuZnSOD was increased on days 7 ( $p<$ $0.05)$ and $12(p<0.01)$, as well as in hibernation $(p<$
0.01). Also, levels of GSH-Px were increased on days 7 and 12 ( $p<0.01$ and $p<0.05$, respectively), and furthermore on days 21 and in hibernation, when the increase was almost 2 -fold $(p<0.001)$. Protein levels of MnSOD showed a marginal increase on day $7(p<0.05)$ and levels of catalase were maintained at control levels during the 21-day cold exposure and in hibernation. 


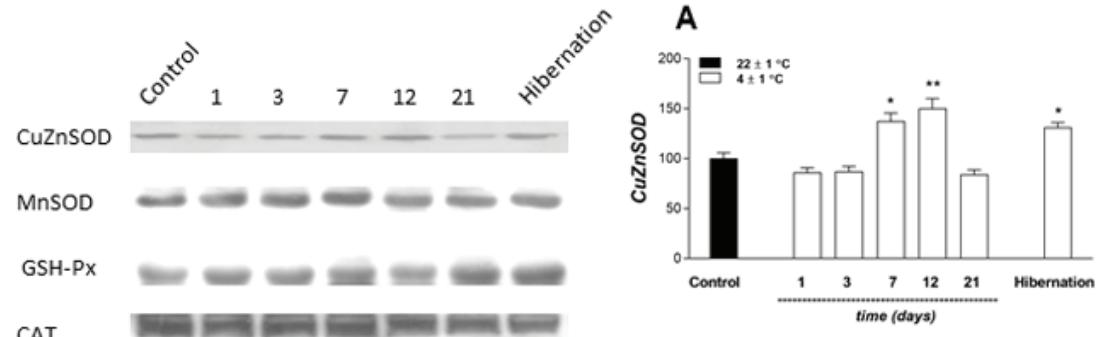

C

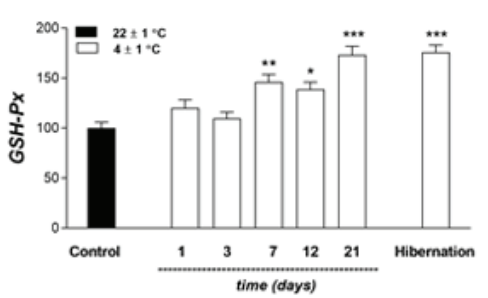

B

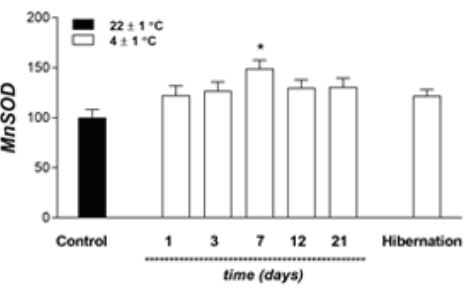

D

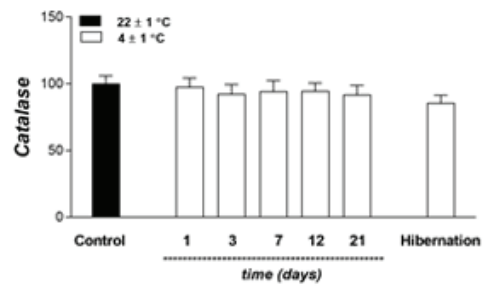

Figure 3. Protein expression profiles of antioxidative defence components: (A) copper-zinc superoxide dismutase (CuZnSOD), (B) manganese superoxide dismutase (MnSOD), (C) glutathione peroxidase (GSH-Px) and (D) catalase (CAT) in the pancreas of cold exposed (1,3,7, 12, or 21 days) and hibernating (2-5 days) ground squirrels. The protein content is expressed relative to a euthermic control, which was standardized as $100 \%$. The signals from representative Western blots are shown. Bars represent the mean \pm S.E.M of three independent immunoblots.

Compared to euthermic control, ${ }^{*} p<0.05,{ }^{* *} p<0.01,{ }^{* * *} p<0.001$.

\section{DISCUSSION}

The results of this study show the changes in mitochondrial oxidative capacity and $A D$ in the pancreas of European ground squirrels during prolonged cold exposure and in hibernation. We observed a marked increase in electron transport chain capacity in response to the three-week cold exposure, especially from the 12 th day onwards, evident from increased protein levels of most respiratory complexes in the later phase of cold acclimation and in hibernation. It seems likely that signaling that precedes and follows the increase in OXPHOS capacity during prehibernation and hibernation is tightly regulated, since there was an upregulation of AMPKa and NRF-1, as well as antioxidative defence.

It has been shown that overall metabolic reorganization during cold acclimation in non-hibernators involves pancreatic tissue at several levels: glucagon secretion, rate of noradrenaline turnover, oxygen consumption and metabolism, exocrine secretion and monoamine oxidase activity [14-19]. The present study suggests that there were metabolic changes in pancreas of hibernators during cold acclimation. To our knowledge, this is the first result showing upregulation of respiratory complexes in hibernators, observed from days 12 to 21 of cold exposure. Respiratory complexes were also upregulated in hibernation. In contrast to the pronounced depletion of energy metabolism in many tissues during hibernation, energy metabolism is maintained in a few select tissues, mostly those essential to overall energy homeostasis and thermogenesis, such as heart, liver, BAT and WAT. In relation to this, our results showing increased expression of respiratory complexes in the pancreas suggest its significant role during the hibernating state. High capacity for energy production in the pancreas of hibernators is possibly linked to its biosynthetic activity, particularly in the context of its endocrine function. Considering that insulin synthesis and secretion are both tightly linked to ATP production i.e. OXPHOS [20], we can speculate that maintaining high respiratory chain capacity during cold acclimation and hibernation is significant for the dynamics of insulin release, especially as the prehibernatory and early hibernation periods have been characterized as hyperinsulinemic [21-24]. Also, the increase in energy-producing capacity in hibernation could be described as a preconditioning mechanism providing a quick metabolic response of this organ during arousal.

The surprising result was the slight decrease in protein levels of ATP synthase during cold acclimation and in hibernation. It is possible that such a decrease does not diminish the significance of the apparent increase in respiratory complexes in terms of electron transport and ATP production, especially in light of the near total energy depression in the hibernating state.

It seems likely from our results that such recruitment of energy-producing pathways in the pancreas of hibernators during cold acclimation occurs in a regulated manner, including AMPKa signaling. Along with the increase in protein levels of respiratory complexes from days 12 to 21 of cold exposure, there was an increase in AMPKa and its downstream effector NRF-1, a positive regulator of respiratory complex transcription. Earlier studies from our laboratory have shown increases in AMPKa levels in skeletal muscle, BAT and WAT of cold acclimating rats $[5,6,25]$. This highlights the role of this enzyme in the metabolic recruitment 
required due to the heightened energy demands of cold acclimation. The return of AMPKa to control levels in hibernating animals suggests that energy demand is fulfilled and also concurs with the notion that AMPKa is not involved in the metabolic remodeling in the hibernating state [26].

The pancreas is particularly vulnerable to high levels of reactive oxygen species, as expression and activity of AD are very low in this tissue [27]. However, our previous results [7], along with the results presented in this study, suggest that the pancreatic AD has the ability to reorganize itself in order to maintain tissue redox state. The observed increase in pancreatic OXPHOS capacity during cold acclimation and hibernation was accompanied by an increase in AD, since levels of GSH-Px and CUZnSOD were elevated during the latter phases of cold acclimation and in hibernation. The marked increase in protein levels of GSH-Px and CuZnSOD observed in this study, in conjunction with the earlier enzyme activity results, albeit in the pancreas of nonhibernators [7], suggests that pancreatic GSH-Px and CuZnSOD have a higher sensitivity for redox changes and that the responsibility for the preservation of redox homeostasis during cold acclimation and in hibernation predominantly lies with these enzymes. Maintenance of these high levels in hibernation represents an important preconditioning phenomenon and could be related to increased ROS production due to sudden intensification of metabolic activity during interbout arousals $[2,28,29]$.

This study gives an insight into the metabolic remodeling of the pancreas during cold acclimation and hibernation, primarily on the level of OXPHOS and AD. In light of the upregulation, or at least maintenance of respiratory chain components and AD enzymes, it is evident that the function of the pancreas is not suppressed, as is the case with many organs and that it plays a vital role in maintaining overall energy homeostasis during cold acclimation and hibernation. Considering the intriguing relationship between insulin and hibernation, we hope to further elucidate the functional (endocrine) significance of these findings in future studies.

\section{REFERENCES}

1. Lyman CP, Willis JS, Malan A, Wang LCH. Hibernation and torpor in mammals and birds, New York Academic, 1982.

2. Carey HV, Andrews MT, Martin SL. Mammalian hibernation: Cellular and molecular responses to depressed metabolism and low temperature. Physiol Rev 2003;83:1153-81.

3. Storey KB, Heldmaier G, Rider MH. Mammalian hibernation: Physiology, cell signaling, and gene controls on metabolic rate depression. Dormancy and resistance in harsh environments, Springer-Verlag Berlin Heidelberg, 2010.
4. Storey KB. Metabolic regulation in mammalian hibernation: Enzyme and protein adaptations. Comp Biochem Physiol 1997;118:1115-24.

5. Vucetic M, Otaševic V, Korac A, Stancic A, Jankovic A, Markelic $M$,et al. Interscapular brown adipose tissue metabolic reprogramming during cold acclimation: Interplay of HIF-1a and AMPKa. Biochim Biophys Acta 2011;1810:1252-61.

6. Stancic A, Buzadzic B, Korac A, Otaševic V, Jankovic A, Vucetic $M$, et al. Regulatory role of PGC-1a/PPAR signaling in skeletal muscle metabolic recruitment during cold acclimation. J Exp Biol 2013;216:4233-41.

7. Petrovic V, Buzadzic B, Korac A, Vasilijevic A, Jankovic A, Korac $B$. Free radical equilibrium in interscapular brown adipose tissue: relationship between metabolic profile and antioxidative defense. Comp Biochem Physiol C Toxicol Pharmacol. 2006;142(1-2):60-5.

8. Petrovic V, Buzadzic B, Korac A, Vasilijevic A, Jankovic A, Micunovic K. Antioxidative defence alterations in skeletal muscle during prolonged acclimation to cold: role of L-arginine/NO-producing pathway. J Exp Biol 2008;211(1):114-20.

9. Vasilijevic A, Buzadzic B, Korac A, Petrovic V, Jankovic A, Micunovic K, et al. The effects of cold acclimation and nitric oxide on antioxidative enzymes in rat pancreas. Comp Biochem Physiol C 2007;145:641-7.

10. Petrovic V, Korac A, Buzadzic B, Korac B. The effects of L-arginine and L- NAME supplementation on redoxregulation and thermogenesis in interscapular brown adipose tissue. J Exp Biol 2005;208:4263-71.

11. Korac A, Buzadzic B, Petrovic V, Vasilijevic A, Jankovic A, Micunovic $K$, et al. The role of nitric oxide in remodeling of capillary network in rat interscapular brown adipose tissue after long-term cold acclimation. Histol Histopathol 2008;23:441-50.

12. Schneider CA, Rasband WS, Eliceiri KW. NIH to ImageJ: 25 years of image analysis. Nat Methods 2012;9:671-5.

13. Lowry $\mathrm{OH}$, Rosenbrough NJ, Farr AL, Randall RJ. Protein measurement with the Folin phenol reagent. J Biol Chem 1951;193:265-75.

14. Harada E, Kanno T. Progressive enhancement in the secretory functions of the digestive system of the rat in the course of cold acclimation. J Physiol 1976;260:62945.

15. Young JB, Landsberg L. Effect of diet and cold exposure on norepinephrine turnover in pancreas and liver. Am J Physiol 1979;236:524-33.

16. Baroody GM, Howland RJ. Insulin secretion by the perfused pancreas of the cold-acclimated rat. Can J Physiol Pharmacol 1980;58:1426-30.

17. Doi K, Ohno T, Kuroshima A. Role of endocrine pancreas in temperature acclimation. Life Sci 1982;30:2253-9.

18. Edwards $\mathrm{Cl}$, Howland RJ. Adaptive changes in insulin and glucagon secretion during cold acclimation in the rat. Am J Physiol 1986;250:669-76.

19. Pizzinat N, Chan SLF, Remaury A, Morgan NG, Parini A. Characterization of monoamine oxidase isoforms in human islets of Langerhans. Life Sci 1999;65:441-8.

20. Fu Z, Gilbert ER, Liu D. Regulation of insulin synthesis and secretion and pancreatic beta-cell dysfunction in diabetes. Curr Diabetes Rev 2013;9:25-53.

21. Florant GL, Lawrence AK, Williams K, Bauman WA. Seasonal changes in pancreatic B-cell function in euther- 
mic yellow-bellied marmots. Am J Physiol Regul Integr Comp Physiol 1985; 249:159-65.

22. Buck MJ, Squire TL, Andrews MT. Coordinate expression of the PDK4 gene: a means of regulating fuel selection in a hibernating mammal. Physiol Genomics 2002;8:513.

23. Martin SL. Mammalian hibernation: A naturally reversible model for insulin resistance in man? Diab Vasc Dis Res 2008;5:76-81.

24. Wu CW, Biggar KK, Storey KB. Biochemical adaptations of mammalian hibernation: exploring squirrels as a perspective model for naturally induced reversible insulin resistance. Braz J Med Biol Res 2013;46:1-13.

25. Jankovic A, Korac A, Buzadzic B, Otaševic V, Stancic A, Vucetic $M$ et al. Endocrine and metabolic signaling in retroperitoneal white adipose tissue remodeling during cold acclimation. J Obes 2013;2013:1-8.
26. Horman S, Hussain N, Dilworth SM, Storey KB, Rider MH. Evaluation of the role of AMP activated protein kinase and its downstream targets in mammalian hibernation. Comp Biochem Physiol B 2005;142:374-82.

27. Lenzen S, Drinkgern J, Tiedge M. Low antioxidant gene expression in pancreatic islets compared with various other mice tissues. Free Radic Biol Medic. 1996;20:463-6.

28. Buzadzic B, Blagojevic D, Korac B, Saicic ZS, Spasic BM, Petrovic VM. Seasonal variation in the antioxidant defense system of the brain of the ground squirrel (Citellus citellus) and response to low temperature compared with rat. Comp Biochem Physiol. 1997;117:141-9.

29. Vucetic $M$, Stancic $A$, Otaševic $V$, Jankovic $A$, Korac $A$, Markelic M, Velickovic K, Golic I, Buzadzic B, Storey KB, Korac B. The impact of cold acclimation and hibernation on antioxidant defenses in the ground squirrel (Spermophilus citellus): An update. Free Radic Biol Med. 2013;65:916-24.

\section{Energetski metabolizam u pankreasu tekunica (Spermophilus citellus) tokom produženog izlaganja hladnoći i u hibernaciji}

\author{
${ }^{1}$ Aleksandra Jankovic, ${ }^{1}$ Andjelika Kalezic, \\ ${ }^{1}$ Strahinja Djuric, ${ }^{2}$ Aleksandra Korac, \\ 'Biljana Buzadzic, 'Bato Korac \\ 'Institut za bioloska istraživanja „Sinisa Stankovic" - \\ Institut od nacionalnog znacaja za Republiku Srbiju, \\ Univerzitet u Beogradu, Bulevar despota Stefana 142, \\ Beograd 11060, Srbija \\ ${ }^{2}$ Centar za elektronsku mikroskopiju, Bioloski fakultet, \\ Univerzitet u Beogradu, Studentski trg 16, Beograd \\ 11000, Srbija
}

\begin{abstract}
Kratak sadržaj
Sisarski hibernatori podležu brojnim biohemijskim adaptacijama koje im omogućavaju preživljavanje niskih temperatura i oskudnost hrane u prirodi. Medjutim, energetski metabolizam u pankreasu tokom hibernacije je još uvek nepoznat. Stoga je u ovoj studiji ispitana molekularna osnova puteva produkcije energije u mitohondrijama u skladu sa njihovim regulacionim mehanizmima, kao i promene antioksidativne odbrane u pankreasu tokom prehibernacionog perioda i u stanju hibernacije. U tu svrhu, mužjaci sezonskog hibernatora Evropske tekunice (Spermophilus citellus) podeljene su u dve grupe, kontrolnu koja je boravila na sobnoj temperaturi $\left(22 \pm 1{ }^{\circ} \mathrm{C}\right)$ i grupu koja je bila izložena niskoj temperaturi $\left(4 \pm 1{ }^{\circ} \mathrm{C}\right)$. Aktivne tekunice su žrtvovane posle 1, 3, 7, 12 i 21 dana izlaganja niskoj temperaturi; životinje koje su ušle u hibernaciju žrtvovane su nakon 2-5
\end{abstract} dana. Rezultati studije su pokazali da je proteinska ekpresija kompleksa I, II, IV elektron transportnog lanca i citohroma c povećana kao odgovor na produženo izlaganje hladnoći (od 12. dana) i da se takvi ekspresioni profili održavaju i u hibernaciji. Paralelno, zapaženo je povećanje ekspresije AMP-aktivirane protein kinaze a (AMPKa) i nuklearnog respiratornog faktora 1 (NRF-1). Štaviše, produženo izlaganje hladnoći i hibernacija izazvale su porast ekspresije antioksidativnih enzima bakar-cink superoksid dismutaze (CuZnSOD) iglutation-peroksidaze (GSH-Px). Rezultati dobijeni u studiji ukazuju na kontrolisano metaboličko remodeliranje u pankreasu tekunica tokom izlaganja hladnoći i u hibernaciji, koje uključuje povećan oksidativni kapacitet mitohondrija, zajedno sa proporcionalnom povecanjem antioksidativne odbrane.

Ključne reči: hibernacija; energetski metabolizam; antioksidativna zaštita; pankreas. 